\title{
Groundwater flow modeling in an intermontane basin
}

\author{
Dinesh Pathak \\ Department of Geology, Tri-Chandra Campus \\ Tribhuvan University, Ghantaghar, Kathmandu, Nepal \\ Email:dpathaktu@gmail.com
}

\begin{abstract}
Groundwater model has become a commonly used tool to perform various tasks. Geological, hydrogeological and geophysical data is required for constructing 3D hydrogeological framework models. Most of the time, it is realised that there is lack of sufficient data to build a groundwater model. The present work has been achieved after systematic data collection and hydrogeological study of Nara Basin, west Japan. Groundwater has been widely exploited for drinking water supply as well as for recreation purpose as Thermal Springs in the Nara Basin. There are hundreds of wells drilled in unconsolidated sediments and some tens of deep wells encountering the fractured basement. When water is exploited from a groundwater basin, it is necessary to understand properly the groundwater flow in different aquifer zones in the basin. Hydrostratigraphic units in the unconsolidated sediments overlying the basement rocks were established by using the borehole log data. In order to have understanding of the three dimensional configuration of these units, fence diagram was constructed. The geological and hydrogeological information were used to develop a conceptual model which was further calibrated and an acceptable model was obtained. The model was validated by comparing the observed and simulated heads and discharge.
\end{abstract}

Keywords: Hydrostratigraphic units, MODFLOW, groundwater flow model, Nara Basin

Received: January 15, 2015

Revision accepted: June 15, 2015

\section{INTRODUCTION}

There is significant impact on the hydrological system at a basin due to intensive water resources development. The resulting impacts are aquifer depletion, cease of base flow, drying of wetlands, degradation of riparian ecosystem and water quality, induced land subsidence and ground cracks. In order to minimize the negative impact on the water resources, it is necessary to consider a river basin as an integrated system where interactions among surface water and groundwater changes during the exploitation of the water resources (Zhou and Li 2011). A groundwater model represents an approximation of a field situation. It is used as a tool to investigate groundwater system dynamics and understanding the flow patterns. It will be helpful to analyse responses of the groundwater system to stresses and also support in assessment for evaluating recharge, discharge and aquifer storage processes, and for quantification. A mathematical model simulates groundwater flow indirectly by means of a governing equation thought to represent the physical processes that occur in the system, together with equations that describe heads or flows along the boundaries of the model. Groundwater model is the best tool to predict the behaviour of groundwater system, such as expected change in groundwater level in an aquifer in future, the capture area for a well field, and the most likely pathway of contaminants. Groundwater models allow more effective use of the available data, more complexities can be accounted for, and the implications of the assumptions used in the analysis and of management decisions can be evaluated (Hamilton 1982).

The present work leading to groundwater flow modeling has been carried out in Nara Basin that is located on west Japan. The basin is surrounded by mountainous terrain and occupies an area of about $770 \mathrm{~km}^{2}$. There are many streams reaching the basin from the surrounding mountains to form Yamato River. Yamato River flows almost through the central part of the Nara Basin towards west. The average elevation of the basin is around $60 \mathrm{~m}$ asl (above sea level), while the height of the surrounding mountain ranges from 470 to $900 \mathrm{~m}$ asl, the highest peak lies in southern part of the study area. The mean annual precipitation in the area is around $1325 \mathrm{~mm}$. There are many wells drilled in the unconsolidated sediments to meet the drinking water demand in the area. Likewise, many deep wells are drilled to exploit the thermal water from the fractured granites for commercial purpose. The detailed hydrogeological studies of the basin was carried out using the information from available water wells (Pathak 2011). The basement structure of the basin was delineated by means of geophysical data (gravity data) aided with the borehole data (Pathak 2006). Likewise, the interaction between the overlying unconsolidated sediments and underlying rocks was thoroughly investigated (Pathak 2003). The objective of the present study is to delineate various aquifer horizons and carry out groundwater flow modelling in the basin. 


\section{Geological setting of the area}

The geology of Nara Basin can be broadly subdivided from top to bottom into the Alluvium (Holocene), Terrace deposits (Upper Pleistocene), Osaka Group (Late PlioceneUpper Pleistocene) and the Cretaceous granitic basement of Ryoke complex (Ikebe and Takenaka 1969). Alluvial deposits consist chiefly of unconsolidated clay, sand and sandy gravels attaining the maximum thickness of $5 \mathrm{~m}$. Whereas the terraces (maximum thickness $20 \mathrm{~m}$ ) are consisting of alternating beds of marine clay with sand and non-marine sandy gravel, sand, and clay (Fig. 1).

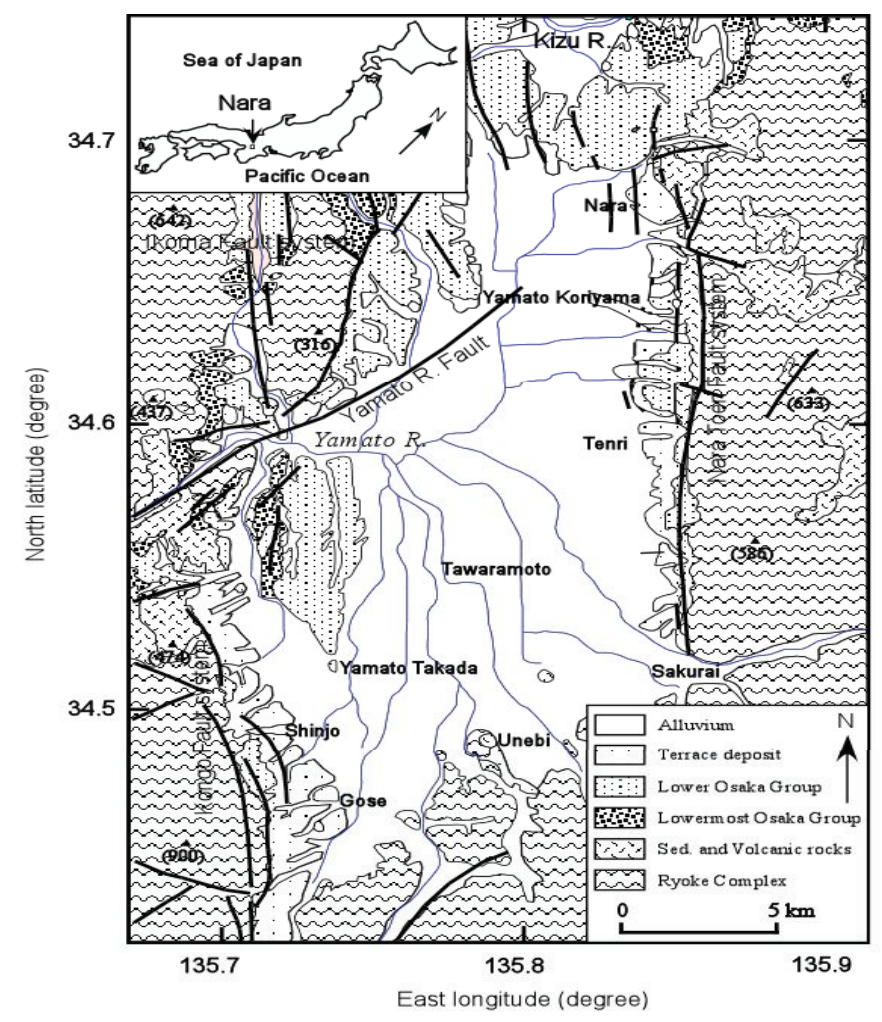

Fig. 1: Geological map of Nara basin (modified after Ikebe and Takenaka 1969). Location of basin in Japan is shown in the inset.

The Osaka Group is further subdivided into the Upper-, Lower- and Lowermost parts (Huzita and Kasama 1983). The Upper and Lower parts consist of alternating beds of marine clay with sand and gravel and non-marine sandy gravel, sand, and clay. The Lowermost part is consisting of non-marine clay, sand, and gravel. The different marine beds occurring at different depths are considered to be the marker beds and are considered to demarcate the geological boundaries of above mentioned units (Itihara 1961, Yoshikawa et al. 1987). The maximum thickness of the Osaka Group is around $600 \mathrm{~m}$. The deep drillings in the northern part of the basin evidences that the maximum thickness of the whole sequence above the Ryoke complex is around $646 \mathrm{~m}$.

The surface of Nara Basin is mostly covered by alluvial deposits. The terrace deposits are exposed along the terraces lying between the hills and the plain area. Likewise, the
Osaka Group sediments can be observed along the foothill, and the Miocene beds (volcanic and sedimentary rocks) are sporadically exposed in some localities. The upper part of Osaka Group is not exposed in the study area (Itihara et al. 1991). In the higher elevation areas, the granitic basement is well exposed, mostly forming higher hills surrounding the basin.

The basement structure in the basin as estimated from the analysis of gravity data shows that the altitude of basement topography is the lowest in the north-eastern part of the basin and the rocks form a NE-SW trending subsurface ridge south of the Yamato River (Pathak 2006). The study reveals that thick alluvial deposits are overlying the basement rocks in the north-eastern part of the basin. Most of the faults in the basin and surrounding mountainous part have approximate northsouth trend, whereas some faults trending in NE-SW direction also exist. The major faults in the area are north-south running Nara-Toen fault system in the north east of the basin and Kongo fault system in the south west of the basin.

\section{MATERIALS AND METHODS}

In order to carry out groundwater flow modelling, it is desirable to have the knowledge of the types of aquifers existing in an area. A 3D digital hydrogeological framework model was developed which defines the physical geometry and materials of hydrogeological units and the hydrogeological structures (Faunt et al. 2004). The top elevation and material distribution of every model layer were specified. The recharge was simulated with the Recharge package of MODFLOW-2000.

Groundwater Modeling System (GMS), a comprehensive graphical user environment that consists of different packages necessary for groundwater modeling has been used at present study. GMS is developed by Brigham Young University (1994) and it incorporates the MODFLOW package (McDonald and Harbaugh 1988, Harbaugh et al. 2000, Harbaugh 2005), a widely used block-centered finite difference groundwater modeling code. A general form of the governing equation used in MODFLOW for modeling the three dimensional groundwater flow is:

$$
\frac{\partial}{\partial x}\left(K_{x} \frac{\partial h}{\partial x}\right)+\frac{\partial}{\partial y}\left(K_{y} \frac{\partial h}{\partial y}\right)+\frac{\partial}{\partial z}\left(K_{z} \frac{\partial h}{\partial z}\right)-W=S_{s} \frac{\partial h}{\partial t}
$$

Where,

$\mathrm{K}_{\mathrm{xx}}, \mathrm{K}_{\mathrm{yy}}, \mathrm{K}_{\mathrm{zz}}$ = values of hydraulic conductivity along $\mathrm{x}$,

$\mathrm{y}$, and $\mathrm{z}$ axes, (m/day)

$\mathrm{h}=$ total head, $(\mathrm{m})$

$\mathrm{W}=$ sources and sinks (volume of outflow from the system per unit volume of aquifer per unit time. In case of inflow, $\mathrm{W}=-\mathrm{R},\left(\mathrm{m}^{3} / \mathrm{m}^{3} \cdot \mathrm{t}\right)$

$\mathrm{S}_{\mathrm{s}}=$ specific storage, $(/ \mathrm{m})$

$\mathrm{t}=$ time, $(\mathrm{t})$

The right hand side of the equation will be reduced to zero while we consider steady state condition, as in present study. 
The modeling process consisted of developing a conceptual model, selecting numerical model, and calibrating the model to observed values, verifying calibrated model and modifying model. The information necessary for the flow modeling are hydrostratigraphic units, hydraulic heads, fluxes in streams, boundary conditions, hydraulic conductivity, and recharge. Development of a conceptual model of the system is the first step in the modeling. The conceptual model simplify the field problem and organize the associated field data so that the system can be analysed more readily. The nature of the conceptual model will determine the dimensions of the numerical model and the design of the grid. The model also requires boundary conditions so that the head or flux would be specified along the boundaries of the system. The natural hydrogeologic boundaries were used in the present analysis as far as possible. The source of surface water to the system as well as the expected flow directions and exit points were part of the conceptual model. The final calibrated model was evaluated by comparing measured and computed groundwater heads and discharges. Good fit to observed groundwater heads occurred and the model was accepted.

\section{RESULTS AND DISCUSSION}

\section{Hydrostratigraphic units}

In modeling regional flow systems, aquifers and confining beds are defined using the concept of the hydrostratigraphic units (Maxey 1964, Seaber 1988). Hydrostratigraphic units comprise geologic units of similar hydrogeologic properties. Based on the lithologic descriptions contained in the water well records, a hydrostratigraphic model of the aquifer system was developed (Pathak 2002). Around 260 borehole logs were available in the basin. The representative boreholes were selected carefully based on the depth of well, information available on the screened zones, and comparing the lithologs of other wells in the vicinity. Finally, 115 of the wells were selected that cover the model area within the basin (Fig. 2). The hydrostratigraphic layers were demarcated with the careful observation of lithologic plots across several sections, both in NS and EW directions. Further, the screened zones in each well site and the hydraulic conductivity values for respective aquifer zones were also taken into account in order to interpolate the aquifer horizons between the wells.

The selected wells were linked into cross-sections and continuous stratigraphic interpolation was carried out. Five aquifer zones were identified which was discretized into numerical flow model input arrays using Hydrogeological Unit Flow package of MODFLOW-2000 (Harbaugh et al. 2000). These aquifers are named as unconfined aquifer (UCA), shallow confined aquifer (SCA), deep confined aquifer 1 (DCA1), deep confined aquifer 2 (DCA2), and deep confined

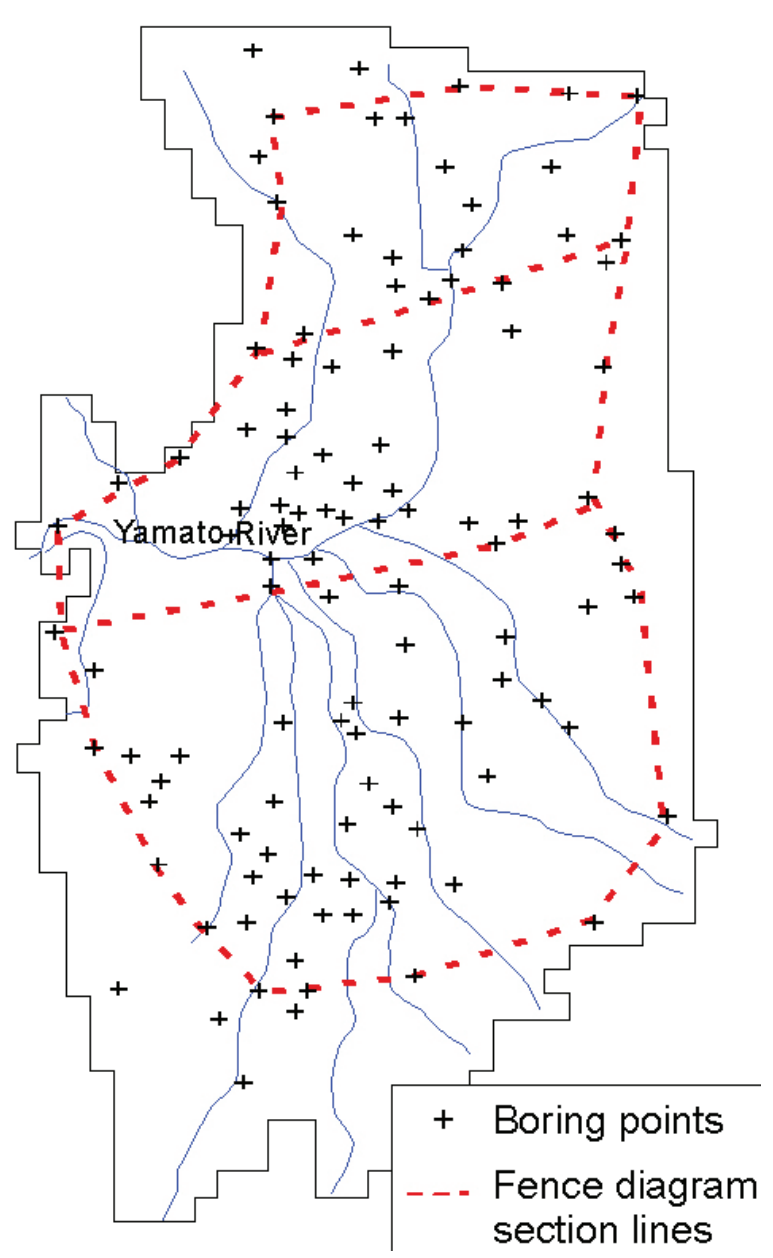

Fig. 2: Lithologs of boreholes that were used to prepare the hydrostratigraphic units.

aquifer 3 (DCA3). The bottom elevation contour of each aquifers were drawn. The altitude of UCA is highest in the northernmost and southernmost part of the study area, reaching up to $120 \mathrm{~m}$ and 150 , respectively and reaches to around $30 \mathrm{~m}$ in the central part. The elevation of the bottom of SCA ranges from around $-10 \mathrm{~m}$ to $110 \mathrm{~m}$. Likewise, the bottom elevations of DCA1, DCA2 and DCA3 ranges from around $-60 \mathrm{~m}$ to 70 $\mathrm{m},-100 \mathrm{~m}$ to $10 \mathrm{~m}$, and $-140 \mathrm{~m}$ to $-20 \mathrm{~m}$, respectively. The gradients of contours are high in northern and south-western parts of the study area. Further, the central part of the basin has lower elevations for all aquifers, the northern and southwestern parts having higher elevations.

The aquifers are thicker in the central and northern part of the basin than in southern part. However, most of the aquifers are thicker in the eastern part than in the western part. A $3 \mathrm{D}$ model of the aquifer geometry is shown in fence diagram (Fig. 3). 


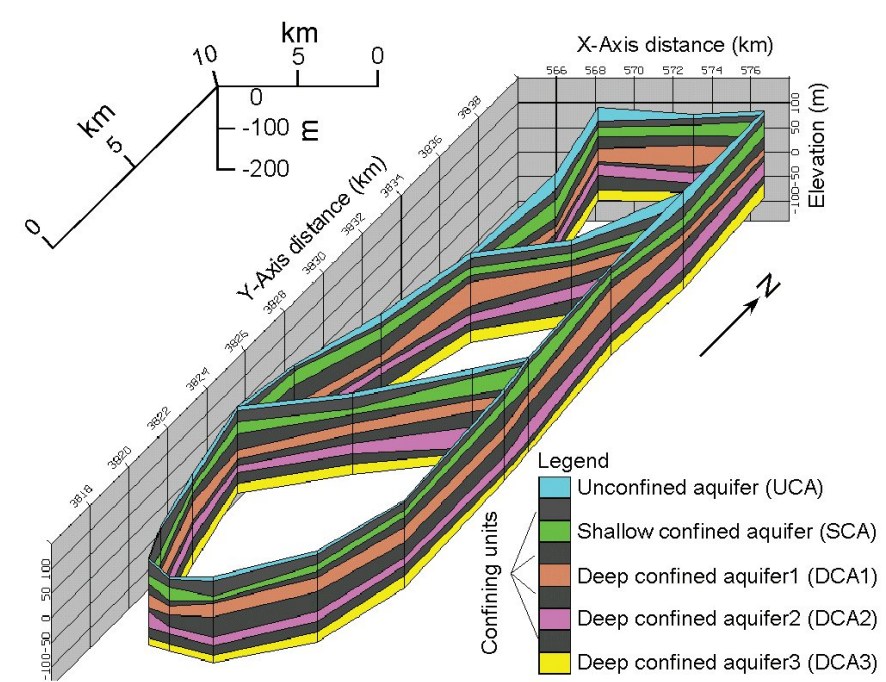

Fig. 3: Fence diagram showing various hydrostratigraphic units in the basin.

The UCA at the topmost part is thick and consists of coarser materials in the north-eastern and mid western part of the study area. In other parts, the unconfined aquifer becomes thinner and the grain size becomes finer. An aquitard separates the unconfined aquifer and shallow confined aquifer. The shallow wells in the basin are exploiting this aquifer horizon, which occurs at the depth of about $30 \mathrm{~m}$ from ground surface. The thickness of this aquifer layer ranges from around $10 \mathrm{~m}$ in the south to $35 \mathrm{~m}$ in central and northern part of the basin, the average thickness is $20 \mathrm{~m}$. South eastern part of the basin is having comparatively finer sized aquifer materials. Other confined aquifer zones lying below the depth of about $50 \mathrm{~m}$ are categorized as deep confined aquifer (DCA). Three deep confined zones are identified within the depth of around 200 $\mathrm{m}$. The average depth of occurrences of these deep confined aquifers are $70 \mathrm{~m}$ (DCA1), $115 \mathrm{~m}$ (DCA2), and $170 \mathrm{~m}$ (DCA3), below the ground surface. Each unit of deep confined aquifers is $25 \mathrm{~m}$ in thickness and separated from each other by confining layers. The lateral variation in thickness of DCA's is rather low in comparison to the UCA and SCA. The aquifer layers are comparatively thicker in the northern, central and around the periphery of basin. The lowermost aquifer (DCA3) is residing above comparatively thicker layer of clay.

\section{Conceptual model}

A conceptual model was developed considering the hydrostratigraphic units, system boundaries, aquifer parameters and hydrologic stresses. The information from the geologic map and the hydrostratigraphic units as well as surface drainage were used to develop a conceptual model.

The boundary of the model area was demarcated based on the geological and topographical map. Model grids were created at an interval $(550 \mathrm{~m} \times 650 \mathrm{~m})$ that was decided to be adequate to carry out flow modeling in the basin (Fig. 4). This grid size was decided by trying different grid sizes and observing the results. Impermeable (No flux) boundary was assigned along the foothill of mountains. These parts are either interface of basin and mountain as in the case of eastern, southern and western part of the study area.

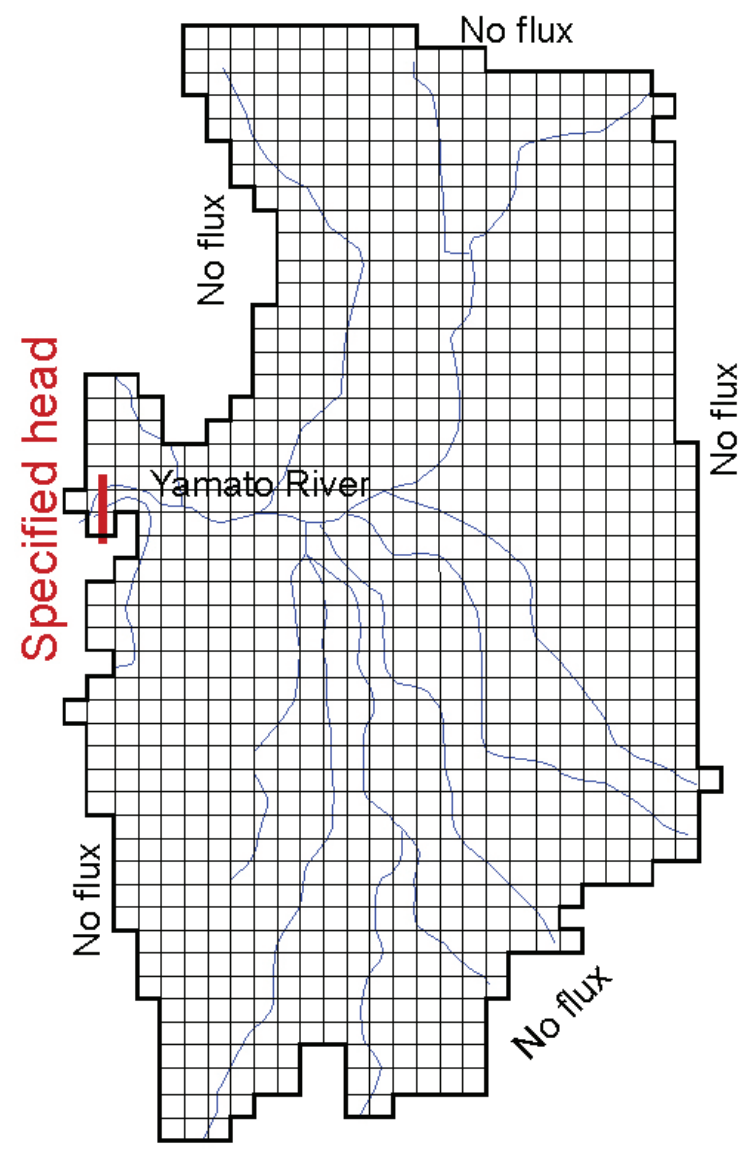

Fig. 4: Model grid and boundary condition.

The Nara Toen fault that is running along the eastern margin of the basin also formed natural no flux boundary. The northern part of the basin was assigned as no flux boundary because it represents the groundwater divide between Yamato River basin in south and the Kizu River basin in the north. The regional groundwater table map also supported for groundwater divide between the two basins. At the exit of Yamato River (mid western part), specified head boundary was assigned.

All the rivers flowing through the basin were used to simulate the exchange of water between the aquifer and the rivers. The water level in each river (River Stage) at the upstream and downstream part and stream bed conductance per unit cross sectional area had been assigned for each river. The conductance is given by the following relationship:

Where,

$$
\mathrm{C}=\mathrm{k}_{\mathrm{v}} \frac{\overline{\mathrm{LW}}}{\mathrm{t}}
$$

$\mathrm{C}=$ conductance of river bed, ( $\mathrm{m} /$ day)

$\mathrm{k}_{\mathrm{v}}=$ vertical hydraulic conductivity of river bed, (m/day)

$\mathrm{L}=$ length of river, (m)

$\mathrm{W}=$ width of river bed, $(\mathrm{m})$

$\mathrm{T}=$ thickness of river bed sediments, $(\mathrm{m})$ 
In order to assign the recharge rates, the basin was divided into two major parts, the high recharge zone and low recharge zone (Fig. 5).

This subdivision was made based on the hydraulic conductivity values, shallow sediment types, drainage and altitude. The initial recharge rate was assigned as $2.10 \times 10^{-3}$ $\mathrm{m} /$ day and $0.76 \times 10^{-3} \mathrm{~m} /$ day for high recharge zone and low recharge zone, respectively. This approximate value was obtained from the mass balance analysis (Oki et al. 1994). In similar way, in and around the Yamato River and northern part of the basin was considered as high hydraulic conductivity zone and that in the southern part as low hydraulic conductivity zone (Fig. 6).

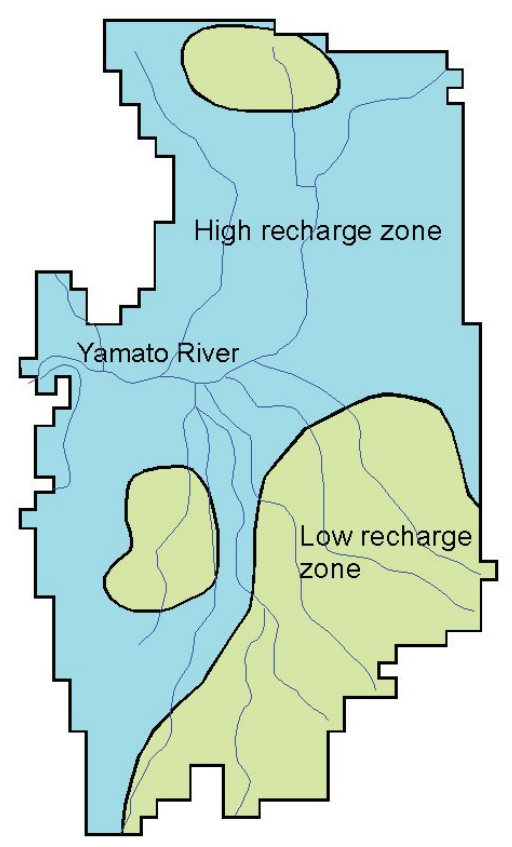

Fig. 5: Demarcation of different recharge zones in the basin.

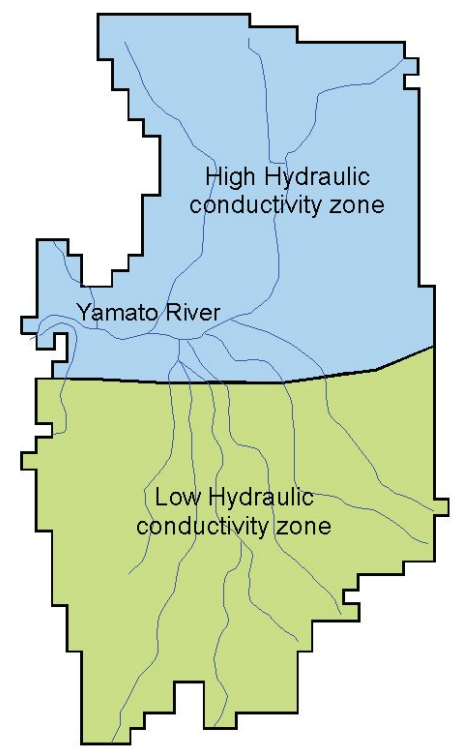

Fig. 6: Demarcation of different hydraulic conductivity zones in the basin.
This subdivision was made based on the hydraulic conductivity parameter obtained from pumping test and estimated from Logan (1964) method using the specific capacity data. The use of Logan method for estimating parameters from specific capacity data is widely used to describe the transmissivity and hydraulic conductivity distribution in the groundwater basin (e.g. Konrad 2006, Pathak 2011, Shibasaki 1999). The conceptual model developed using all the available information on hydrostratigraphy, geology, hydrology and hydrogeology was used to generate flow model of the basin, using the MODFLOW (McDonald and Harbaugh 1988) in Groundwater Modeling System (GMS 1994).

\section{Model calibration}

Model calibration is viewed as a process to develop a useful groundwater model. The purpose of calibration is to establish that the model can reproduce field-measured heads and flows. Effective model calibration includes the entire modeling process. Guidelines for effective model calibration using automatic parameter identification (nonlinear regression) have been proposed by Hill and Tiedeman (2007). Calibration is the process of modifying the input parameters to a groundwater model until the output from the model matches an observed set of data like heads and recharge. Input parameters such as hydraulic conductivity and recharge are very difficult to estimate. Calibration is achieved when computed results are within a "window" of the observed value.

The water level data used for the model calibration were from the wells (shallow and deep), which represented the long term water level measurement data (Fig. 7).

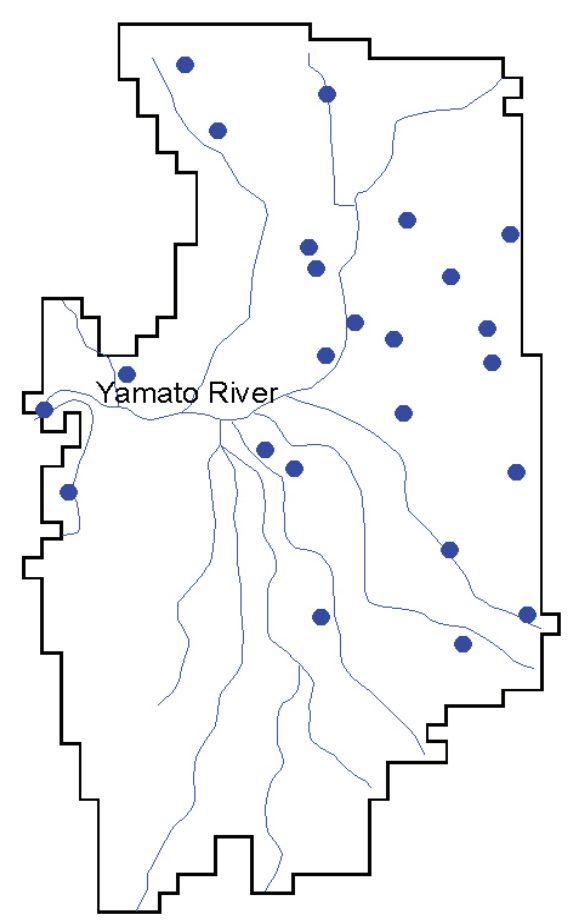

Fig. 7: Location of observation wells in the basin used for model calibration. 
An inverse parameter estimation application, named UCODE (Poeter and Hill 1998) was used to estimate the model parameters. During each stages of adjustment of some parameter values, the computed and observed heads were compared. A final model was developed that has the observed and computed heads very close, with mean error: $8.12 \mathrm{~m}$, mean absolute error: $10 \mathrm{~m}$, and RMS error: $9.7 \mathrm{~m}$. This can be considered as a reasonable match between the computed and simulated heads (Yao et al. 2015, Konrad 2006). The comparison between observed and simulated heads is shown in Fig. 8. The parameters finally used in the model are summarized in Table 1.

\section{Simulation results}

The result of simulation can be presented either in the form of head contour or flux contour. The cell by cell flux data sets can be used to plot fluxes. The flux vector is useful for illustrating flow directions. Besides, flow budget for each layer can be read from the output file.

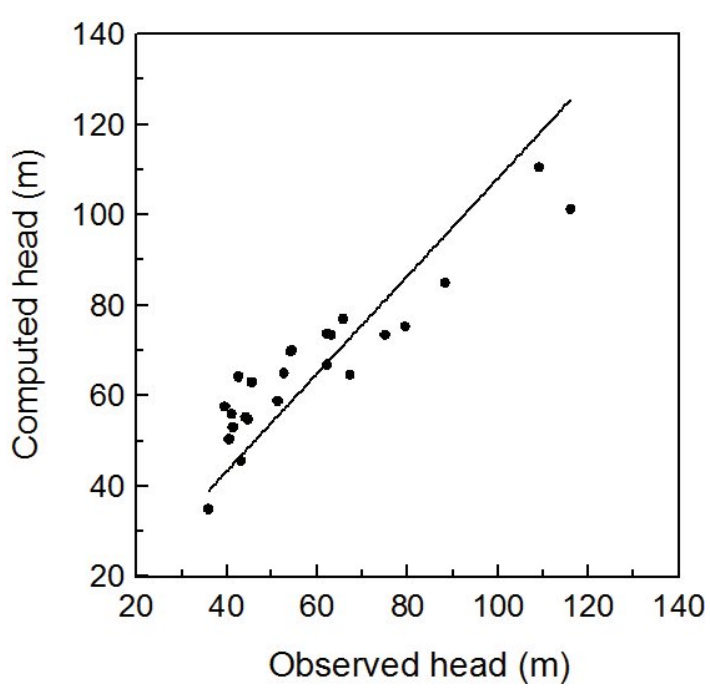

Fig. 8: Comparison between observed and computed heads.

Table 1: Recharge and horizontal hydraulic conductivity values used in final model.

\begin{tabular}{|c|c|c|c|c|c|c|c|}
\hline Par & & 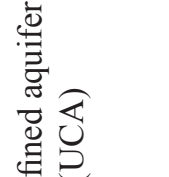 & 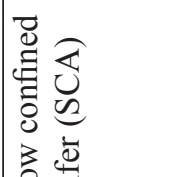 & 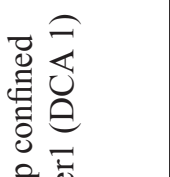 & 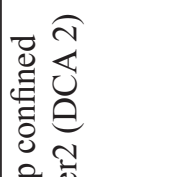 & 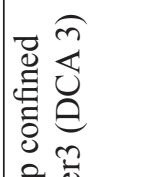 & 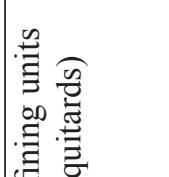 \\
\hline & Zone A & $6.573 \times 10^{-3}$ & - & - & - & - & - \\
\hline Recharge (m/day) & Zone B & $0.175 \times 10^{-3}$ & - & - & - & - & - \\
\hline Horizontal hydraulic & Zone 1 & 289.0 & 37.0 & 16.0 & 16.0 & 16.0 & $1 \times 10^{-3}$ \\
\hline conductivity (m/day) & Zone 2 & 104.0 & 23.0 & 4.0 & 4.0 & 4.0 & $1 \times 10^{-3}$ \\
\hline
\end{tabular}

Note: Zone A and Zone B are high and low recharge zones, respectively (Fig. 5). Zone 1 and Zone 2 are high and low hydraulic conductivity zones, respectively (Fig. 6). Vertical hydraulic conductivity is assumed to 10\% of horizontal hydraulic conductivity.

The computed water level in all aquifers is having same trend as that of the regional water table contour. Similar trend of water level was also observed in the historical heads distribution in the basin (Oki et al. 1994). The computed heads for all the layers are somewhat following the basin shape and orientation (Fig. 9 to Fig. 13), the minimum being in the midwestern part, around the exit of Yamato River. The head value normally ranges from about $30 \mathrm{~m}$ to $110 \mathrm{~m}$ above sea level. The highest value lying in the northernmost and southernmost part of the model area. The heads in UCA is also controlled by the river system in the basin as the contour is almost following the rivers in the central and northern part (Fig. 9).

The flux is of higher magnitude in the northern part than in the south. However, in the south-western part of the model area, comparatively higher flux can be observed. The flux vectors shows groundwater is flowing towards the center of the basin.

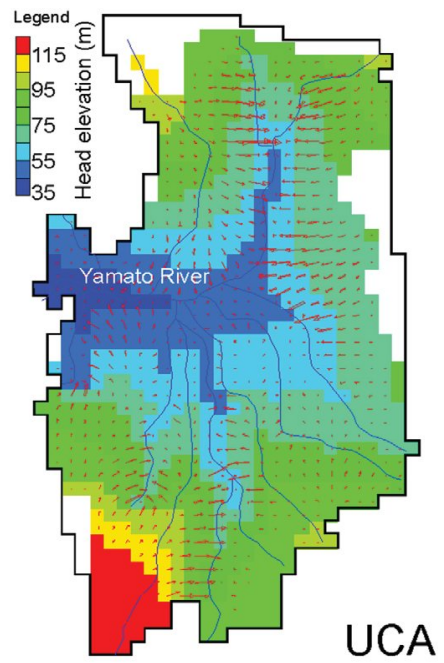

Fig. 9: Computed heads and flux vectors in the unconfined aquifer (UCA). 
The computed heads for SCA show similar trend that of UCA showing that there is a considerable exchange of mass between the surface water system and the SCA (Fig. 10).

The heads for DCA units show relatively smooth contour because of uniform distribution of pressure at the deeper aquifers. However, the contour values are decreasing towards the center of the basin, the minimum being at the exit point of the Yamato River. The flux vectors is higher for all DCA units in northern part of the basin (Figs. 11, 12 and 13).

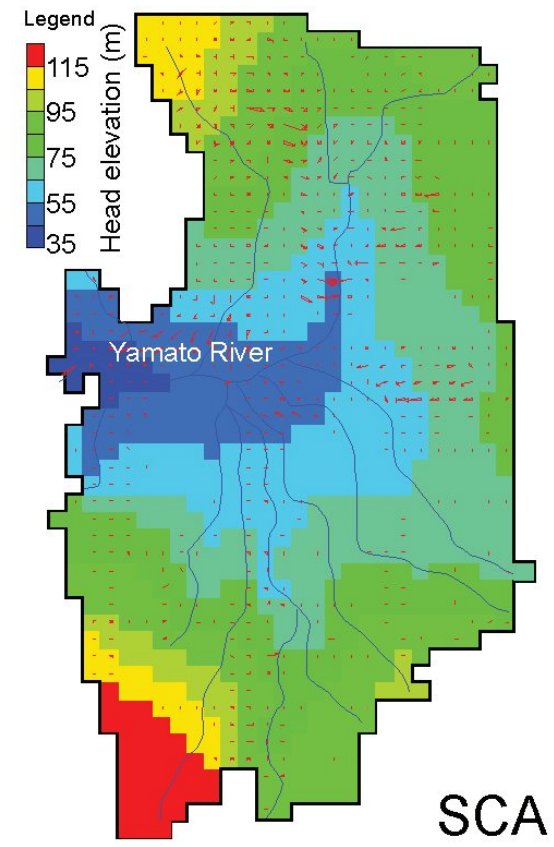

Fig. 10: Computed heads and flux vectors in the shallow confined aquifer (SCA).

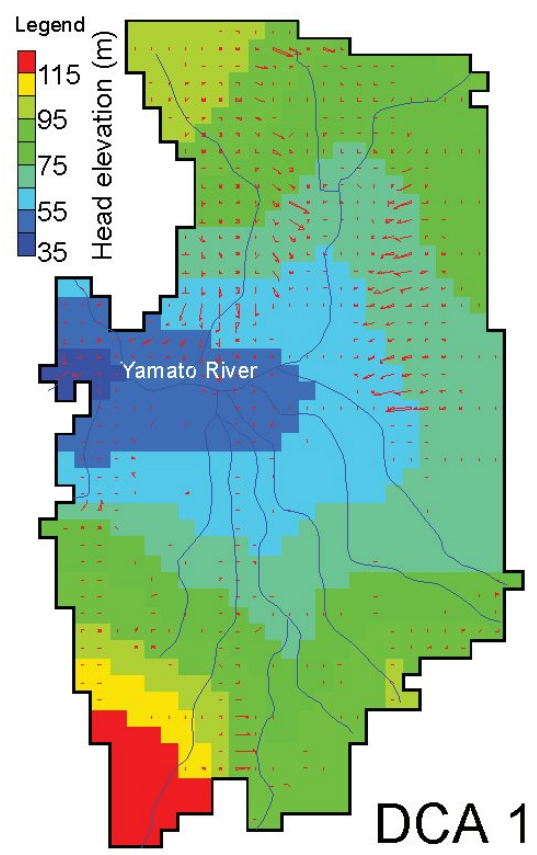

Fig. 11: Computed heads and flux vectors in the deep confined aquifer 1 (DCA1).

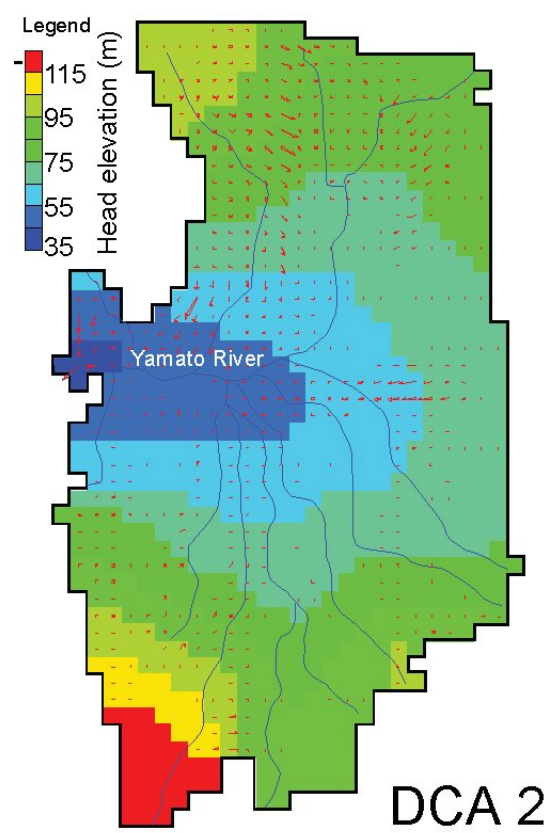

Fig. 12: Computed heads and flux vectors in the deep confined aquifer 2 (DCA2).

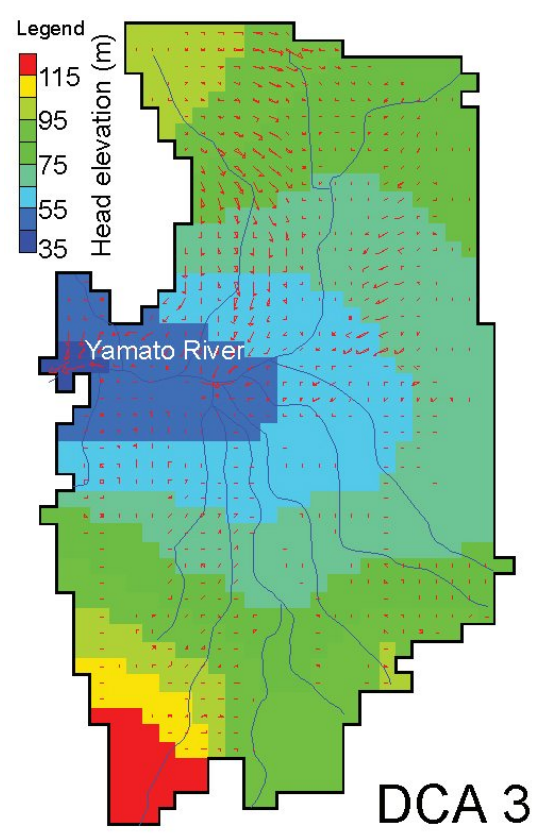

Fig. 13: Computed heads and flux vectors in the deep confined aquifer 3 (DCA3).

The relative magnitude of flux vector in the aquifers is more in the northern part. This is in good agreement to the result obtained from analysing hydrogeological and structural data of the basin. The northern part being a potential area for groundwater exploitation. Further, in all the confined aquifer, the flux vector shows upward direction because of confining pressure. However, in unconfined aquifer, UCA, the flux vector indicates that groundwater is moving downward in the mideastern part of the study area. 
The total amount of flux from rivers in the basin is computed to be 2.23 million cubic meter per day (MCM/day). This value is very close to the observed value $1.92 \mathrm{MCM} /$ day during the period of 1980 to 1988 (Oki and Ono 1994). The good agreement in computed heads to the historical head and computed flux and measured flux shows that the present model well represents the natural condition of aquifers. Likewise, total amount of computed recharge in the basin is $1.30 \mathrm{MCM} /$ day. Total amount of water flowing through the unconfined aquifer is $1.22 \mathrm{MCM} /$ day. This value for SCA, DCA1, DCA2, and DCA3 are $1.15,0.95,0.72$ and $0.56 \mathrm{MCM} /$ day, respectively.

\section{CONCLUSIONS}

The groundwater flow modeling has been carried out in Nara Basin through preparing a hydrostratigraphic model using about 250 water well logs. This model represents for the depth of around $200 \mathrm{~m}$ and five units are identified in the model, which are unconfined aquifer at the top, shallow confined aquifer and other three units of deep confined aquifers. The unconfined aquifer unit is thin, around 3-5 m, while each of the other four confined units is about $25 \mathrm{~m}$ thick. Using these hydrostratigraphic units, and other parameters, a groundwater flow model of the basin is generated. The calibrated flow model reasonably represents the real field condition. The computed water level in the unconfined aquifer is affected by the surface drainage. However, for the other confined aquifer units, the effect of river is less. The relative magnitude of flux vector in the aquifers is more in the northern part. This is in good agreement to the result obtained from analysing hydrogeological and structural data of the basin.

The model shows that groundwater flux rate is high in the northern part of the basin for all aquifer units. The computed groundwater head contours indicate that groundwater is flowing towards the center of the basin (towards Yamato River). The good agreement between the computed heads to the historical head and computed flux and measured flux shows supports that the present model well represents the natural condition of aquifers.

\section{ACKNOWLEDGEMENT}

The author is grateful to Dr. Koichi Nakagawa, Prof. Emeritus, Osaka City University, Japan for providing necessary facilities to carry out the study. The support provided by Mr. M. Sato, Tokushu Plant Industry Co., Ltd., Osaka Branch through providing well data is kindly acknowledged. Special thanks go to Dr. S. Nakaya, Shinshu University for providing the useful information related to groundwater of Nara Basin. Mr. M. Shibayama generously helped to collect groundwater data of monitoring wells from different government organizations.

\section{REFERENCES}

Faunt, C. C., Sweekind, D. S. and Belcher, W. R., 2004, Threedimensional Hydrogeological Framework Model. Chapter E of Death Valley Regional Groundwater Flow System, Nevada and California-Hydrogeological Framework and
Transient Groundwater Flow Model. U.S. Geological Survey. Scientific Investigation Report 2004-5205.

Groundwater Modeling System (GMS), 1994, Brigham Young University, USA.

Hamilton, D. A., 1982, Groundwater modeling: selection, testing and use. Michigan department of natural resources, v. $1,199 \mathrm{p}$.

Harbaugh, A. W., Banta, E. R., Hill, M. C. and McDonald, M. G. 2000, MODFLOW-2000, the U. S. Geological Survey modular ground-water model-user guide to modularization concepts and the Ground-Water Flow Process. U.S. Geological Survey Open-File Report 00-92, 121 p.

Harbaugh, A. W., 2005, MODFLOW-2005, the U.S. Geological Survey modular ground-water model-the Ground-Water Flow Process. U.S. Geological Survey Techniques and Methods 6-A16.

Hill, M. C., Tiedeman, C. R., 2007, Effective Groundwater Model Calibration, with Analysis of Sensitivity, Predictions and Uncertainty. Wiley, New York, 480 p.

Huzita, K. and Kasama, T., 1983, Geology of the Kobe District, Quadrangle series (1:50,000 scale). Geol. Survey of Japan. (in Japanese with English abstract).

Ikebe, N. and Takenaka, J., 1969, Geologic structure of Osaka Basin. Report on land subsidence in Osaka, pp. 446-455.

Itihara, M., 1961, Some problems of the Quaternary sedimentaries in the Osaka and Akashi areas. Japan. Jour. Institute of polytechnics, Osaka City University, v. 5, pp. 21-27.

Itihara, M., Yoshikawa, S., Mitamura, M., Mizuno, K. and Hayashi, T., 1991, 1:125,000 Quaternary geological map of Osaka and adjacent areas, Kinki, Japan. Urban Kubota, no. 30.

Konrad, C. P., 2006, Longitudinal hydraulic analysis of riveraquifer exchanges. Water Resour. Res., v. 42, W08425, doi: 10.1029/2005WR004197.

Logan, J., 1964, Estimating transmissibility from routine production tests of water wells. Groundwater, v. 2, pp. 35-37.

Maxey, G. B., 1964, Hydrostratigraphic units. Jour. Hydro., v. 2, pp. 124-129.

McDonald, M. G. and Harburg, A. W., 1988, A modular threedimensional finite-difference groundwater flow model, techniques of water resources. Investigations 06-S1, USGS, $576 \mathrm{p}$.

Oki, T., Nakaya, S., and Itoh, M., 1994, Hydrogeology of Nara Basin (Part 3): Simulating the interaction between surface water and groundwater (Nara bonchi ni okeru chikasui (sono 3). Jour. Groundwater Tech. (Nihon chikasui rikagaku kenkyusho), v. 34(12), pp. 40-50 (in Japanese).

Oki, T. and Ono, K., 1994, Hydrogeology of Nara Basin (Part 1): Extractable volume and utilization condition (Nara 
bonchi ni okeru chikasui (sono 1). Jour. Groundwater Tech. (Nihon chikasui rikagaku kenkyusho), v. 36(10), pp. 40-55 (in Japanese).

Pathak, D., 2002, Basement structure, hydrogeology and groundwater flow model of Nara Basin, southwest Japan. Ph. D. thesis, Osaka City University, Japan, 129 p.

Pathak, D., 2003, Heat flow and vertical groundwater flux in deep fractured basement rock in Nara Basin, southwest Japan. Jour. Nepal Geol. Soc., v. 28, pp. 101-111.

Pathak, D., 2006, Delineation of basement structure from gravity data: example from Nara basin, Japan. Jour. Nepal Geol. Soc., v. 33, pp. 39-44.

Pathak, D., 2011, Hydrogeology of shallow and deep aquifers in Nara Basin, West Japan. Jour. Nepal Geol. Soc., v. 43, pp. 267-275.

Poeter, E. P. and Hill, M. C., 1998, Documentation of UCODE, A Computer Code for Universal Inverse Modeling. U.S. Geol. Surv., Water Resources Investigations, Report 984080.

San Juan, C. A., Belcher, W. R., Laczniak, R. J. and Putnam, H. M., 2004, Hydrological Components for Model Development Chapter C of Death Valley Regional
Groundwater Flow System, Nevada and CaliforniaHydrogeological Framework and Transient Groundwater Flow Model. U.S. Geol. Surv., Scientific Investigation Report 2004-5205.

Seaber, P. R., 1988, Hydrostratigraphic units. In Hydrogeology, The Geology of North America (Eds: Back, W., Rosenschein, J. R. and Seaber, P. R.), Geological Society of America, v. O-2, pp. 9-14.

Shibasaki, N., 1999, Study of methodology of practical parameter estimation for groundwater modeling based on hydrogeological classification. Jour. Geosci., Osaka City University, v. 42, pp. 21-44.

Yao, Y., Zheng, C., Liu, J., Cao, G., Xiao, H., Li, H. and Li, W., 2014, Conceptual and numerical models for groundwater flow in an arid inland river basin. Hydrol. Process, Wiley Online Library (wileyonlinelibrary.com). doi: 10.1002/ hyp. 10276.

Yoshikawa, S., Nakagawa, K., Kawabe, T., Furutani, M. and Daishi, M., 1987, Reconstruction of OD-2 and OD-1 core samples in Osaka City, Central Japan. Jour. Geosci., Osaka City University, v. 93, pp. 1-1.

Zhou, Y. and Li, W., 2011, A review of regional groundwater flow modelling. Geoscience Frontiers, v. 2(2), pp. 205214. doi:10.1016/j.gsf.2011.03.003. 